\section{Comparison of Anthracnose Resistance with the Presence of Two SCAR Markers Associated with the Rca2 Gene in Strawberry}

\author{
Melinda A. Miller-Butler ${ }^{1}$ and Barbara J. Smith ${ }^{2}$ \\ U.S. Department of Agriculture, Agriculture Research Service, Poplarville, \\ MS 39470
}

\author{
Brian R. Kreiser \\ Department of Biological Sciences, University of Southern Mississippi, \\ Hattiesburg, MS 39406
}

\author{
Eugene K. Blythe \\ Coastal Research and Extension Center, Mississippi State University, South \\ Mississippi Branch Experiment Station, Poplarville, MS 39470
}

Additional index words. strawberry, Fragaria $\times$ ananassa, molecular markers, Colletotrichum acutatum, Colletotrichum gloeosporioides

\begin{abstract}
Strawberry anthracnose diseases are caused primarily by three Colletotrichum species: C. acutatum J.H. Simmonds, C. fragariae A.N. Brooks, and C. gloeosporioides (Penz.) Penz. \& Sacc. Molecular markers are being used in breeding programs to identify alleles linked to disease resistance and other positive agronomic traits. In our study, strawberry cultivars and breeding germplasm with known anthracnose susceptibility or resistance to the three anthracnose-causing Colletotrichum species were screened for two sequence characterized amplified region (SCAR) markers linked to the Rca 2 gene. The Rca 2 resistant allele SCAR markers were associated with varying degrees of significance for a strawberry plant's anthracnose resistance to $C$. fragariae but not to $C$. acutatum or $C$. gloeosporioides. Although the presence or absence of the markers associated with the $\boldsymbol{R} \boldsymbol{c a} 2$ resistance gene is an imperfect indicator of anthracnose resistance, it may serve as a useful starting point in selecting germplasm for breeding programs.
\end{abstract}

In the southeastern United States, anthracnose diseases of commercial strawberry (Fragaria Xananassa Duch.) are caused primarily by three Colletotrichum species: C. acutatum, C. fragariae, and $C$. gloeosporioides (Maas, 1998). Colletotrichum acutatum incites two major anthracnose diseases on strawberry: anthracnose fruit rot and root necrosis (Howard et al., 1992; Mertely and Peres, 2012; Mertely et al., 2005), and has been found to remain latent on symptomless strawberry plants (Leandro et al., 2001). The devastating Colletotrichum crown rot (anthracnose crown rot) may be caused by $C$.

\footnotetext{
Received for publication 7 Dec. 2018. Accepted for publication 12 Mar. 2019.

The use of trade, firm, or corporation names in this publication is for the information and convenience of the reader. Such use does not constitute an official endorsement or approval by the U.S. Department of Agriculture or the Agricultural Research Service of any product or service to the exclusion of others that may be suitable.

${ }^{1}$ Current address: Jones County Junior College, Ellisville, MS 39437

${ }^{2}$ Corresponding author. E-mail: Barbara.Smith@ ars.usda.gov.

This is an open access article distributed under the CC BY-NC-ND license (http://creativecommons. org/licenses/by-nc-nd/4.0/).
}

gloeosporioides or C. fragariae (Howard et al., 1992; Peres et al., 2007; Smith, 1998; Smith and Black, 1987; Ureña-Padilla et al., 2002). Both C. gloeosporioides and C. fragariae may also cause anthracnose symptoms on all aerial parts of the strawberry plant. Fungicides are used routinely to control anthracnose diseases; however, frequent use of the same fungicides has resulted in their failure to control anthracnose as a result of pathogen resistance (Forcelini and Peres, 2018; LaMondia, 1995; Smith and Black, 1992, 1993). The need for fungicides can be reduced by growing strawberry cultivars resistant to anthracnose diseases.

Strawberry breeders and plant pathologists are working to develop strawberry germplasm resistant to anthracnose crown rot and fruit rot diseases using traditional and classic techniques (Denoyes and Guerin, 1996; Salinas et al., 2018; Whitaker et al., 2017), and are exploring native germplasm for sources of anthracnose resistance in strawberry (Lenne and Wood, 1991; Lewers et al., 2007). Various protocols have been developed to screen strawberry seedlings and mature plants for resistance to the different Colletotrichum species. Denoyes and Guerin (1996) screened for resistance to C. acutatum by immersing whole plants into a conidial suspension of the pathogen. Horowitz et al.
(2004) developed a foliar-dip method for large-scale screening of 12- and 15-weekold strawberry seedlings for resistance to $C$. gloeosporioides and C. acutatum. A protocol for identifying strawberry germplasm with resistance to $C$. fragariae based on petiole and crown symptoms was developed at the U.S. Department of Agriculture-Agricultural Research Service, Poplarville, MS (Smith and Black, 1987; Smith and Spiers, 1982) and was used to select anthracnose-resistant germplasm with desirable horticultural characteristics. Selections from this program were given the prefix MSUS, and one anthracnose resistant cultivar, 'Pelican' (Smith et al., 1998), and four anthracnose resistant breeding lines-US70, US159, US292, and US438 (Galletta et al., 1993)-developed in this program were released. Recently the anthracnose resistance/susceptibility of 31 strawberry cultivars was compared with that of 50 anthracnose-resistant MSUS selections developed at Poplarville, MS (Miller-Butler et al., 2018).

Most strawberry cultivars are octoploids, which presents difficulties in determining their genetics in classic breeding programs (Anciro et al., 2018; Hancock et al., 2008). Disomic inheritance for at least part of the strawberry genome has been demonstrated by some researchers (Folta and Davis, 2006; Lerceteau-Köhler et al., 2003), which allows breeders to identify dominant and recessive alleles for these loci. The advent of molecular genetics provided plant breeders with molecular markers to use for identification of alleles linked to disease resistance and other positive agronomic characteristics (Longhi et al., 2014). Genetic marker-assisted detection of resistance genes has been used in various Fragaria-pathogen systems, including the following: locating the $R p c 1$ gene that provides resistance to crown rot disease caused by Phytophthora cactorum in Fragaria vesca (Davik et al., 2015); screening strawberry seedlings in field trials for resistance to $V$. dahlia, the causative agent of verticillium wilt (Antanaviciute et al., 2015); identifying the Rpfl gene for resistance to red stele root rot caused by Phytophthora fragariae (Van de Weg et al., 1997); locating a quantitative trait locus (QTL) conferring resistance to C. gloeosporioides (Anciro et al., 2018); and detecting the subgenomespecific locus FaRCal conferring resistance to C. acutatum (Salinas et al., 2018). SCAR markers were used to demonstrate a resistant:susceptible segregation ratio of $1: 1$ in strawberry progeny from crosses between red stele-susceptible $\times$-resistant germplasm (Gel Vonauskienè et al., 2007).

Several studies have tested strawberries for resistance to C. acutatum, which has been classified as either pathogenicity groups 1 or 2 , based on its pathogenicity on five strawberry cultivars (Denoyes and Baudry, 1995). Classification of additional C. acutatum isolates was performed by Denoyes-Rothan et al. (2003), who conducted pathogenicity tests on two strawberry cultivars-Belrubi (resistant to group 2 and susceptible to group 
1) and Elsanta (susceptible to both groups)using a subset of 34 European $C$. acutatum isolates and the American C. acutatum isolate Goff. Denoyes-Rothan et al. (2005) examined the inheritance of high- and intermediate-level plant resistance to $C$. $a c u$ tatum isolates of pathogenicity group 2 and found that the inheritance of a dominant gene (Rca2) controlled strawberry resistance to that group. Lerceteau-Köhler et al. (2005) identified two SCAR markers and used them to screen European and American strawberry genotypes, reported in the literature as resistant or susceptible, for the presence of the Rca 2 gene. They found 13 of the 28 resistant genotypes had both SCAR markers and none of the 14 susceptible genotypes had either of the SCAR markers. They considered their results to be indicative of monogenic control for resistance to $C$. acutatum pathogenicity group 2.

In our study we investigated the possibility that strawberry germplasm containing the Rca2 gene with resistance to group $2 C$. acutatum isolates might also confer a level of resistance to $C$. fragariae and $C$. gloeosporioides, as well as to $C$. acutatum isolates for which a pathogenicity group has not been determined. The objective of our research was to screen 31 strawberry cultivars and 50 MSUS selections for the presence or absence of the two SCAR markers linked to the Rca2 gene and to determine whether their presence or absence in each germplasm line correlates with the resistance/susceptibility to each of the three Colletotrichum species as reported by Miller-Butler et al. (2018). Knowledge of the presence or absence of the Rca2 gene and a germplasm's resistance to anthracnose should improve breeders' decisions concerning which strawberry germplasm is most desirable to incorporate into breeding programs.

\section{Materials and Methods}

Plant material and fungal isolates. Thirty-one cultivars and 50 MSUS clones, referred to collectively as germplasm lines (Miller-Butler et al., 2018), were screened for anthracnose resistance using five Colletotrichum isolates: two isolates of $C$. acutatum (Goff and Ca-1), two isolates of C. fragariae (Cf-63 and Cf-75), and one isolate of $C$. gloeosporioides (Cg-162) (Chang and Smith, 2007; Smith and Black, 1990). These five isolates were identified initially based on cultural morphology, but sequence analysis of the $\beta$-tubulin 2 (TUB2) gene further classified the two $C$. fragariae isolates as $C$. theobromicola. Glyceraldehyde-3-phosphate dehydrogenase sequences further classified the $C$. acutatum isolates as $C$. nymphaeae, and the $C$. gloeosporioides isolate as $C$. fructicola (Miller-Butler et al., 2018; Munir et al., 2016).

DNA Extractions and Allele Identification. The same collection of plants used in the study by Miller-Butler et al. (2018) was the source of leaves for allele identification. Fresh strawberry leaves were ground in liquid nitrogen.
DNA was extracted from 50 to $90 \mathrm{mg}$ of the ground tissue using a DNeasy Plant Mini Kit from Qiagen (Valencia, CA) and quantified with a Nanodrop ${ }^{\circledR}$ ND-1000 spectrophotometer (Thermo Fisher Scientific, Inc., Wilmington, DE). The extracted DNA was used in a polymerase chain reaction (PCR) to amplify the SCAR markers STS-Rca2 240 and STS-Rca2_417 (Lerceteau-Köhler et al., 2005).

The STS-Rca2_240 SCAR marker was multiplexed with the Fragaria vesca microsatellite EMFv020 (Hadonou et al., 2004) to serve as a positive control for the PCR. Amplification conditions adapted from LerceteauKöhler et al. (2005) included a total volume of $25 \mu \mathrm{L}$ with $1 \times$ reaction buffer (P2192; Sigma-Aldrich, Inc., St. Louis, MO), $0.8 \mathrm{U}$ JumpStart Taq DNA Polymerase (D9307; Sigma-Aldrich, Inc.), $0.2 \mathrm{~mm}$ deoxynucleotide (dNTP) mix (D7295; Sigma-Aldrich, Inc.), $0.2 \mu \mathrm{M}$ of each primer, CAC_240_2F and CAC_240_2Rb, $0.08 \mu \mathrm{M}$ of each control primer, EMFv020_F and EMFv020_R (Sigma-Aldrich, Inc.), and 20 to 40 ng DNA template. PCR conditions consisted of a 3-min denaturation at $95{ }^{\circ} \mathrm{C}, 35$ cycles of $50 \mathrm{~s}$ at $95{ }^{\circ} \mathrm{C}, 50 \mathrm{~s}$ at $64{ }^{\circ} \mathrm{C}$, and $1 \mathrm{~min}$ at $72{ }^{\circ} \mathrm{C}$, with a final extension step of $5 \mathrm{~min}$ at $72{ }^{\circ} \mathrm{C}$. The amplification product was separated on a $1 \%$ agarose gel and then stained with ethidium bromide. Electrophoresis gels were photographed with a Kodak EDAS 290 (Carestream Health, Rochester, NY) on a Spectroline ultraviolet Transilluminator (Westbury, NY) and visualized with Kodak 1D Software (Scientific Imaging Systems, New Haven, CT). Individual strawberry germplasm lines were classified according to the presence or absence of the marker associated with the resistance allele.

The amplification procedure for the STSRca2_417 marker, adapted from LerceteauKöhler et al. (2005), was carried out in a total volume of $25 \mu \mathrm{L}$ with $1 \times$ reaction buffer (P2192, Sigma-Aldrich, Inc.), 0.8 U JumpStart Taq DNA Polymerase, $0.2 \mathrm{~mm}$ dNTP mix, $0.2 \mu \mathrm{M}$ of the M13 tailed CAC 417 3F primer (Boutin-Ganache et al., 2001), $0.2 \mu \mathrm{M}$ of the CAC_417_3R primer (Sigma-Aldrich), $0.1 \mu \mathrm{M}$ of the M13 labeled primer (LI-COR, Lincoln, NE), and 20 to $40 \mathrm{ng}$ of template DNA. PCR conditions were the same as for the STS-Rca2_240 marker except for the annealing temperature of $62{ }^{\circ} \mathrm{C}$. The amplification product was visualized using a LI-COR 4300 DNA sequencer using a $6.5 \%$ polyacrylamide gel with a 50- to 700-bp size standard (LICOR Biosciences, Lincoln, NE) and was scored using Gene Image IR (ver. 3.55, LICOR). Each strawberry germplasm line was tested two to three times for each SCAR marker to confirm its genotype.

Statistical analysis Two methods of statistical analysis were used. First, generalized linear models (binomial distribution and logit link function) were used to model the main effects and interaction of the presence/ absence of the two SCAR markers in predicting resistance/susceptibility of the 81 strawberry lines ( 31 cultivars and 50 germplasm clones) as the sample population. These logistic models were run using the GLIMMIX procedure of SAS (ver. 9.4; SAS Institute Inc., Cary, NC). Second, $2 \times 2$ contingency tables for selected tests (single-marker, multimarker, and single-allele tests) vs. resistance/ susceptibility of the 81 strawberries were used to run Fisher's exact test and calculate additional metrics: accuracy, positive predictive value (precision), negative predictive value, sensitivity, specificity, and (most importantly) the adjusted diagnostic odds ratio (ADOR). Fisher's exact test was run using the FREQ procedure of SAS and the additional metrics were calculated following the methods used by Salinas et al. (2017). Separate analyses were run for each of the three species of Colletotrichum.

\section{Results}

Allele identification. DNA was extracted from the same 81 strawberry germplasm lines used in the plant inoculations (Miller-Butler et al., 2018) and was tested for the STSRca2_240 and STS-Rca2_417 markers. Of the 31 cultivars tested, 22 were positive for the STS-Rca2_240 marker and 21 were positive for the STS-Rca2_417 marker (Table 1). Both the STS-Rca2_240 and STS-Rca2_417 markers were present in 16 cultivars, and the STS-Rca2_417 marker was present without the STS-Rca2_240 marker in five cultivars. Ten cultivars tested negative for the STS-Rca2_417 marker. Fifty MSUS clones were tested for the two markers, including the breeding lines US70, US159, US292, and US438. The STS-Rca2_240 marker was found in 42 MSUS clones, the STS-Rca2 417 marker was found in 34 MSUS clones, both markers were present in 29 MSUS clones, and five MSUS clonesincluding US70, US159, and US292-had the STS-Rca2_417 marker without the STSRca2_240 marker.

During identification of the STS-Rca2 417 marker, other alleles measuring 421, 415, and $397 \mathrm{bp}$ were observed. Lerceteau-Köhler et al. (2005) noted alleles measuring $421 \mathrm{bp}$ and $397 \mathrm{bp}$, but did not mention a 415-bp allele. The 421-bp allele was found in 20 cultivars and 39 MSUS clones. The 415-bp allele was not found in any cultivar tested but was found in six MSUS clones, and the 397-bp allele was found in 20 cultivars and 40 MSUS clones. The presence of the STS-Rca2_240 and STS-Rca2_417 SCAR markers in cultivars used in the research by Lerceteau-Köhler et al. (2005) and were also used in this study are found in Table 1.

Association of SCAR markers and plant resistance. The disease severity rating (DSR) of each strawberry germplasm line for the Colletotrichum isolates were combined as species (DSR of $C$. acutatum species $=$ DSRs of isolates Ca-1 and Goff combined, DSR of C. fragariae species $=\mathrm{DSRs}$ of isolates $\mathrm{Cf}-63$ and Cf-75 combined, and DSR of C. gloeosporioides species $=$ DSR isolate Cg-162). These DSRs were used to classify the disease response category for each strawberry 
Table 1. Strawberry genotype, anthracnose disease severity rating following inoculation with three species of Colletotrichum, and presence or absence of sequence characterized amplified region (SCAR) markers and alleles in this study and in a European study (Lerceteau-Köhler et al., 2005).

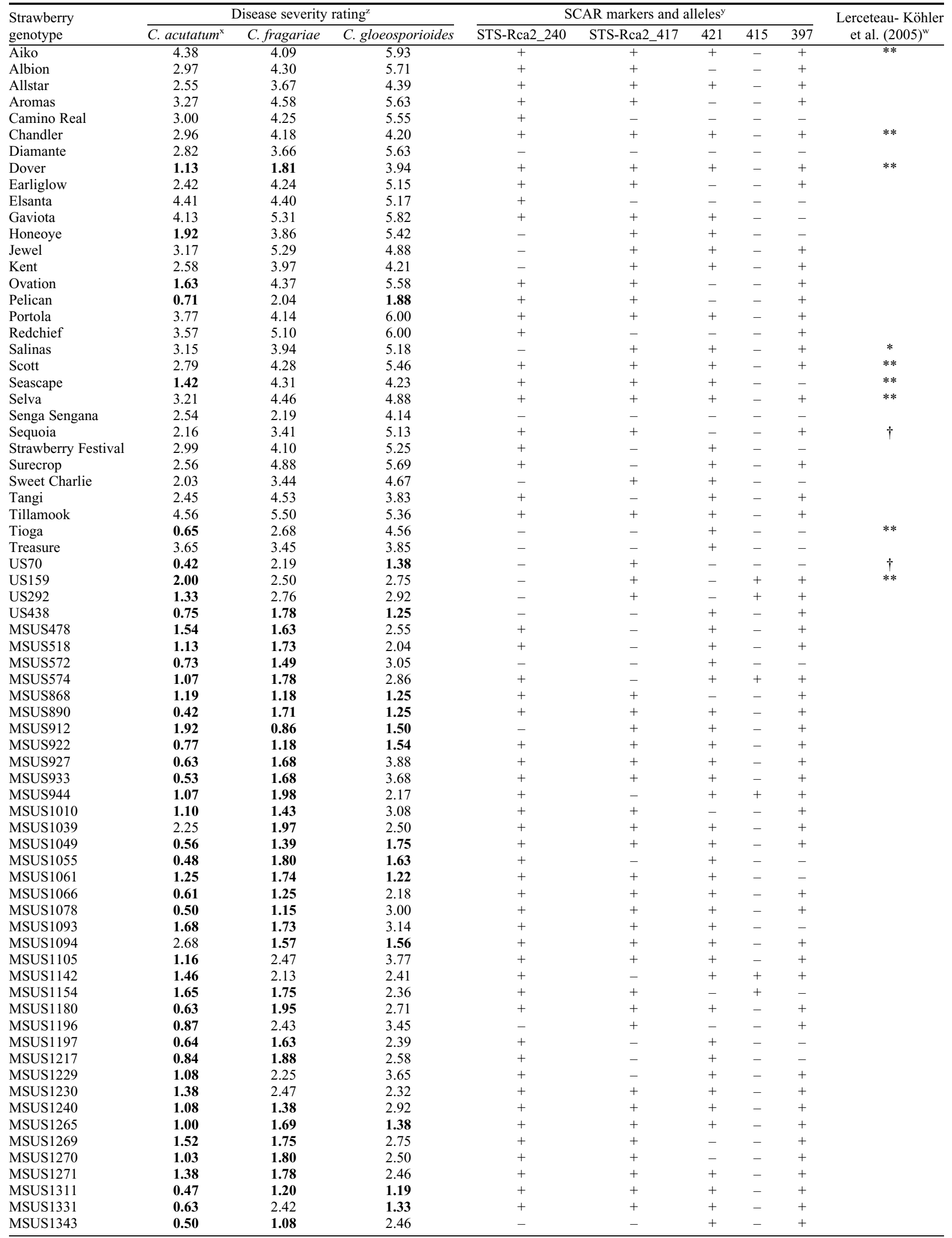

(Continued on next page) 
Table 1. (Continued) Strawberry genotype, anthracnose disease severity rating following inoculation with three species of Colletotrichum, and presence or absence of sequence characterized amplified region (SCAR) markers and alleles in this study and in a European study (Lerceteau-Köhler et al., 2005).

\begin{tabular}{|c|c|c|c|c|c|c|c|c|c|}
\hline \multirow{2}{*}{$\begin{array}{l}\text { Strawberry } \\
\text { genotype }\end{array}$} & \multicolumn{3}{|c|}{ Disease severity rating ${ }^{z}$} & \multicolumn{5}{|c|}{ SCAR markers and alleles ${ }^{\mathrm{y}}$} & \multirow{2}{*}{$\begin{array}{l}\text { Lerceteau- Köhler } \\
\text { et al. }(2005)^{\mathrm{w}}\end{array}$} \\
\hline & C. acutatum $^{\mathrm{x}}$ & C. fragariae & C. gloeosporioides & STS-Rca2_240 & STS-Rca2_417 & 421 & 415 & 397 & \\
\hline MSUS1352 & 1.04 & 1.95 & 2.63 & + & + & - & - & + & \\
\hline MSUS1356 & 0.95 & 1.69 & 1.05 & + & - & + & - & - & \\
\hline MSUS1359 & 0.43 & 1.50 & 1.91 & + & - & + & - & + & \\
\hline MSUS1362 & 1.54 & 1.40 & 1.96 & + & - & + & - & + & \\
\hline MSUS1365 & 1.84 & 1.81 & 2.00 & + & + & + & - & + & \\
\hline MSUS1426 & 1.53 & 2.00 & 1.46 & + & + & + & - & - & \\
\hline MSUS1432 & 0.63 & 1.00 & 1.75 & + & + & - & - & + & \\
\hline MSUS1494 & 0.75 & 2.63 & 0.67 & + & - & + & - & + & \\
\hline MSUS1511 & 0.90 & 1.97 & 2.20 & + & + & + & - & + & \\
\hline
\end{tabular}

${ }^{\mathrm{z}}$ Values in bold type indicate a disease severity rating $\leq 2.0$ and a resistant anthracnose disease response category.

${ }^{\mathrm{y}}$ SCAR marker identification in our study and other alleles identified using primers for STS-Rca2_417: $+=$ marker of allele present, $-=$ absent.

${ }^{\mathrm{x}}$ Colletotrichum species used in plant inoculations: C. acutatum isolates Ca-1 and Goff, C. fragariae isolates Cf-63 and Cf-75, and C. gloeosporioides isolate Cg-162.

${ }^{w}$ SCAR marker identification in Lerceteau-Köhler et al. (2005): * = positive for STS-Rca2_240, $\dagger=$ positive for STS-Rca2_417, and $* *=$ positive for both STS-Rca2_240 and STS-Rca2_417.

germplasm line as resistant $(\mathrm{DSR} \leq 2.0)$ or susceptible (DSR > 2.0). The disease response category for each strawberry germplasm line was compared with our SCAR marker data using generalized linear models to model the main effects and interaction of the presence/absence of the two SCAR markers in predicting resistance/susceptibility (Table 2). The effect of the STSRca2_240 marker was significant for resistance to $C$. fragariae $(P=0.04)$, but not significant for resistance to $C$. acutatum or $C$. gloeosporioides. The effect of the STSRca2_417 marker was not significant for resistance to C. acutatum, C. fragariae, or C. gloeosporioides. The effect of the interaction between the STS-Rca2_240 and STSRca2_417 markers also was not significant for resistance to C. acutatum, C. fragariae, or C. gloeosporioides.

A second analysis of each of the three species of Colletotrichum based on Fisher's exact test and the ADOR, used to compare diagnostic tests for which the better test has a greater ADOR (Glas et al., 2003), indicated little or no ability of the two SCAR markers or the three alleles to predict anthracnose resistance of the germplasm lines (Table 3 ). Fisher's exact test did indicate significant effects of the STS-Rca2_240 marker and the 421-bp allele for resistance to $C$. fragariae $(P=0.01$ and 0.05 , respectively). The greatest sensitivity values $(\leq 0.90)$ were for the 417-bp allele for all three Colletotrichum species and the STS-Rca2_240 marker for C. fragariae, whereas the greatest specificity values were for the 415-bp allele for all three Colletotrichum species. All the ADORs were small, but the highest four ADORs were for the 415-bp allele for resistance to C. acutatum $(\mathrm{ADOR}=7.4)$ and the STSRca2_240 marker, the 421-bp allele, and the combination of the STS-Rca2_240 and STS-Rca2_417 markers for resistance to $C$. fragariae $(\mathrm{ADOR}=4.1,2.8$, and 2.3 , respectively).

\section{Discussion}

The objective of this research was to quantify the association between the resistance of strawberry germplasm to anthracnose diseases caused by each of three Colletotrichum species and the presence or absence of the two SCAR markers linked to the Rca2 gene for resistance to C. acutatum pathogenicity group 2 (Lerceteau-Köhler et al., 2005). Strawberry germplasm used in this study were identified as resistant or susceptible to isolates of each of the three Colletotrichum species. The majority of cultivars were classified as susceptible to the three Colletotrichum species; MSUS clones were classified as mainly resistant to $C$. acutatum and $C$. fragariae (which was expected because they had been selected based on their resistance to C. fragariae), and either resistant or susceptible to C. gloeosporioides.

Strawberry germplasm lines with both the STS-Rca2_240 and STS-Rca2_417 markers, or the STS-Rca2_417 marker alone were predicted to be resistant to C. acutatum based on findings by Lerceteau-Köhler et al. (2005) that the two alleles were linked to a dominant gene, Rca2, for resistance to anthracnose disease caused by $C$. acutatum group 2 isolates. Their study included 43 cultivars, of which 28 (65\%) were resistant to C. acutatum group 2 and carried either both the STSRca2_240 and STS-Rca2_417 markers or the STS-Rca2_417 marker alone. Thirteen of the $28(46 \%)$ resistant cultivars contained both the STS-Rca2_240 and STS-Rca2_417 markers, and eight carried the STS-Rca2_417 markers only; this correctly predicted $75 \%$ $(21 / 28)$ of the cultivars as resistant. Results of our research with $C$. acutatum-inoculated cultivars predicted 15 of 21 (71\%) cultivars should be resistant, with 10 having both the STS-Rca2_240 and STS-Rca2_417 markers and five with the STS-Rca2_417 marker only. However, only four cultivars (19\%) were resistant to $C$. acutatum, and one of those had neither marker. Of the 22 cultivars predicted by the study of Lerceteau-Köhler et al. (2005) to be susceptible to C. acutatum by the absence of both markers, only 14 were found to be susceptible. Likewise, three germplasm lines in our study had neither marker, which predicted them to be susceptible to $C$. acutatum; however, of these three lines, two were classified as susceptible ('Treasure' and 'Senga Sengana') and one was classified as resistant ('Tioga'). Our research confirmed the presence or absence of the markers in 10 of the 18 cultivars used in the European study (Lerceteau-Köhler et al., 2005) (Table 1). Our detection of a 415-bp allele not reported previously could possibly be a result of our use of a greater concentration polyacrylamide gel to separate the fragments $(6.5 \%$ vs. $4.5 \%)$ (LerceteauKöhler et al., 2005).

Our research found the SCAR markers STS-Rca2_240 and STS-Rca2_417 had no significant effects on disease resistance of germplasm lines when inoculated with $C$.

Table 2. F tests from logistic models for the effects of the presence/absence of the two sequence characterized amplified region markers STS-Rca2_240 and STSRca2_417, and their interaction on resistance to anthracnose disease on strawberry plants (31 cultivars and 50 germplasm clones) inoculated with isolates of three Colletotrichum species.

\begin{tabular}{|c|c|c|c|c|c|c|c|c|}
\hline \multirow[b]{2}{*}{ Fixed effects } & \multirow[b]{2}{*}{ No. df } & \multirow[b]{2}{*}{ Den df } & \multicolumn{2}{|c|}{ C. acutatum $^{2}$} & \multicolumn{2}{|c|}{ C. fragariae } & \multicolumn{2}{|c|}{ C. gloeosporioides } \\
\hline & & & $\mathrm{F}$ & $P>\mathrm{F}$ & $\bar{F}$ & $P>\mathrm{F}$ & $\bar{F}$ & $P>\mathrm{F}$ \\
\hline STS-Rca2_417 & 1 & 77 & 0.01 & 0.90 & 1.30 & 0.26 & 0.13 & 0.72 \\
\hline STS-Rca2_240 × STS-Rca2_417 & 1 & 77 & 0.01 & 0.93 & 2.44 & 0.12 & 0.04 & 0.85 \\
\hline
\end{tabular}

${ }^{\mathrm{z}}$ Colletotrichum species used in plant inoculations: $\mathrm{Ca}=$ C. acutatum isolates $\mathrm{Ca}-1$ and $\mathrm{Goff}, \mathrm{Cf}=$ C. fragariae isolates Cf-63 and $\mathrm{Cf}-75$, and $\mathrm{Cg}=$ C. gloeosporioides isolate Cg-162. 
Table 3. Adjusted diagnostic odds ratios (ADORs) for testing the ability of two sequence characterized amplified region markers (using single-marker and multimarker tests) and three alleles to predict the resistance of strawberry plants (consisting of 31 cultivars and 50 germplasm clones) to anthracnose disease when inoculated with isolates of three Colletotrichum species. $^{\mathrm{z}}$

\begin{tabular}{|c|c|c|c|c|c|c|c|}
\hline Test & $P$ value & $\begin{array}{c}\text { Accuracy } \\
(\%)\end{array}$ & $\begin{array}{c}\text { Positive predictive } \\
\text { value }\end{array}$ & $\begin{array}{c}\text { Negative predictive } \\
\text { value }\end{array}$ & Sensitivity & Specificity & ADOR \\
\hline \multicolumn{8}{|l|}{$\overline{\text { C. acutatum }}$} \\
\hline STS-Rca2_240 present & 0.5638 & 63.0 & 0.69 & 0.41 & 0.81 & 0.26 & 1.55 \\
\hline STS-Rca2_417 present & 1.0000 & 56.8 & 0.67 & 0.35 & 0.69 & 0.33 & 1.10 \\
\hline $421 \mathrm{bp}$ allele present & 0.4317 & 61.7 & 0.69 & 0.41 & 0.76 & 0.33 & 1.58 \\
\hline $415 \mathrm{bp}$ allele present & 0.1713 & 40.7 & 1.00 & 0.36 & 0.11 & 1.00 & 7.37 \\
\hline 397 bp allele present & 0.6008 & 60.5 & 0.68 & 0.38 & 0.76 & 0.30 & 1.34 \\
\hline STS-Rca2_240 and/or STS-Rca2_417 present & 0.6808 & 65.4 & 0.68 & 0.43 & 0.93 & 0.11 & 1.60 \\
\hline STS-Rca2_240 and STS-Rca2_417 present & 0.6444 & 54.3 & 0.69 & 0.36 & 0.57 & 0.48 & 1.25 \\
\hline \multicolumn{8}{|l|}{ C. fragariae } \\
\hline STS-Rca2_240 present & 0.0148 & 61.7 & 0.58 & 0.76 & 0.90 & 0.33 & 4.09 \\
\hline STS-Rca2_417 present & 1.0000 & 50.6 & 0.51 & 0.50 & 0.68 & 0.33 & 1.04 \\
\hline $421 \mathrm{bp}$ allele present & 0.0479 & 60.5 & 0.58 & 0.68 & 0.83 & 0.38 & 2.80 \\
\hline $415 \mathrm{bp}$ allele present & 1.0000 & 49.4 & 0.50 & 0.49 & 0.07 & 0.93 & 0.97 \\
\hline 397 bp allele present & 0.4551 & 54.3 & 0.53 & 0.57 & 0.78 & 0.30 & 1.50 \\
\hline STS-Rca2_240 and/or STS-Rca2_417 present & 0.7123 & 51.9 & 0.51 & 0.57 & 0.93 & 0.10 & 1.36 \\
\hline STS-Rca2_240 and STS-Rca2_417 present & 0.0752 & 60.5 & 0.60 & 0.61 & 0.66 & 0.55 & 2.31 \\
\hline \multicolumn{8}{|l|}{ C. gloeosporioides } \\
\hline STS-Rca2_240 present & 0.5376 & 39.5 & 0.28 & 0.82 & 0.86 & 0.23 & 1.65 \\
\hline STS-Rca2_417 present & 0.7900 & 43.2 & 0.27 & 0.77 & 0.71 & 0.33 & 1.21 \\
\hline $421 \mathrm{bp}$ allele present & 0.4035 & 43.2 & 0.29 & 0.82 & 0.81 & 0.30 & 1.69 \\
\hline $415 \mathrm{bp}$ allele present & 0.3311 & 66.7 & 0.00 & 0.72 & 0.00 & 0.90 & 0.19 \\
\hline $397 \mathrm{bp}$ allele present & 1.0000 & 39.5 & 0.27 & 0.76 & 0.76 & 0.27 & 1.11 \\
\hline STS-Rca2_240 and/or STS-Rca2_417 present & 0.6702 & 32.1 & 0.27 & 0.86 & 0.95 & 0.10 & 1.63 \\
\hline STS-Rca2_240 and STS-Rca2_417 present & 0.6122 & 50.6 & 0.29 & 0.78 & 0.62 & 0.47 & 1.39 \\
\hline
\end{tabular}

${ }^{\mathrm{z} C o l l e t o t r i c h u m ~ s p e c i e s ~ u s e d ~ i n ~ p l a n t ~ i n o c u l a t i o n s: ~ C . ~ a c u t a t u m ~ i s o l a t e s ~ C a-1 ~ a n d ~ G o f f, ~ C . ~ f r a g a r i a e ~ i s o l a t e s ~ C f-63 ~ a n d ~ C f-75, ~ a n d ~ C . ~ g l o e o s p o r i o i d e s ~ i s o l a t e ~}$ Cg-162.

acutatum isolates Goff and Ca-1. Colletotrichum acutatum isolate Goff was classified as a pathogenicity group 1 isolate as a result of its pathogenicity to both 'Belrubi' and 'Elsanta' (Denoyes-Rothan et al., 2003). 'Elsanta' was included in our study and was rated susceptible to both C. acutatum isolates Goff and Ca-1. 'Belrubi' was unavailable and not included in our study. Isolate $\mathrm{Ca}-1$ has not been assigned to either pathogenicity group. The fact that our C. acutatum isolates, Goff and $\mathrm{Ca}-1$, could represent two pathogenicity groups may explain the differences between the resistance of cultivars to $C$. acutatum found in this study and that found in the European study. The Rca 2 resistance gene was identified for resistance to isolates in pathogenicity group 2 and is controlled by a single dominant gene (Denoyes-Rothan et al., 2005), whereas anthracnose resistance to isolates in pathogenicity group 1 was recently reported to be polygenic (Denoyes et al., 2017). Salinas et al. (2018) used pedigree-based QTL analysis to identify a major dominant resistance locus, FaRCal, that appears to confer resistance to C. acutatum isolates of pathogenicity group 1 .

The presence of the STS-Rca2_240 marker in our study had a significant effect $(P=0.01)$ on disease resistance with germplasm lines inoculated with $C$. fragariae but not with $C$. gloeosporioides $(P=0.54)$. The presence of the STS-Rca2_417 marker did not have a significant effect on disease resistance for either C. fragariae or C. gloeosporioides. This weak association between the presence of the STS-Rca2_240 SCAR marker and resistance to $C$. fragariae with no significant association between the presence of the STS-Rca2_417 SCAR marker and resistance to $C$. fragariae or between either of these markers and resistance to $C$. gloeosporioides suggests that pathogenicity in these species operates via pathways not prone to regulation by the Rca2 gene.

These SCAR markers for anthracnose resistance are an example of the application of molecular approaches to selecting breeding lines that are becoming increasingly more common. Strawberry breeders at the University of Florida are using high-throughput genome scanning and pedigree-based QTL analysis to identify resistance to crown $\operatorname{rot}(C$. gloeosporioides), angular leaf spot (Xanthomonas fragariae), and crown and root rot (P. cactorum) (Whitaker et al., 2017). SCAR markers developed for the Rpf1 gene are being used to identify strawberry germplasm with resistance to $P$. fragariae (Haymes et al., 2000; Rugienius et al., 2006). DenoyesRothan et al. (2005) demonstrated that a single gene appears to be linked to resistance to $C$. acutatum pathogenicity group 2 . Although the SCAR markers developed by Lerceteau-Köhler et al. (2005) are not diagnostic for resistance to anthracnose diseases incited by $C$. gloeosporioides, C. fragariae, or $C$. acutatum pathogenicity group 1 isolates, they are part of a growing molecular toolbox available to aid strawberry breeders in making better decisions concerning their breeding germplasm.

\section{Literature Cited}

Anciro, A., J. Mangandi, S. Verma, N. Peres, V.M. Whitaker, and S. Lee. 2018. FaRCgl: A quantitative trait locus conferring resistance to Colletotrichum crown rot caused by Colletotrichum gloeosporioides in octoploid strawberry. Theor. Appl. 131:2167-2177.
Antanaviciute, L., N. Surbanovski, N. Harrison, K.J. McLeary, D.W. Simpson, F. Wilson, D.J. Sargent, and R.J. Harrison. 2015. Mapping QTL associated with Verticillium dahlia resistance in the cultivated strawberry (Fragaria Xananassa). Hort. Res. 2:15009, doi: 10.1038/ hortres.2015.9.

Boutin-Ganache, I., M. Raposo, M. Raymond, and M. Deschepper. 2001. M13-tailed primers improve the readability and usability of microsatellite analyses performed with two different allele-sizing methods. Biotechniques 31:24-28.

Chang, P. and B.J. Smith. 2007. Response of 'Treasure' and 22 Florida strawberry genotypes to the anthracnose pathogens Colletotrichum acutatum, C. fragariae, and C. gloeosporioides, p. 69-73. In: F. Takeda, D.T. Handley, and E.B. Poling (eds.). Proceedings of the 2007 North American Strawberry Symposium. North American Strawberry Growers Association, Kemptville, ON, Canada.

Davik, J., H. Eikemo, M.B. Brurberg, and D.J. Sargent. 2015. Mapping of the RPc-l locus for Phytophthora cactorum resistance in Fragaria vesca. Mol. Breed. 35:1-11.

Denoyes, B. and A. Baudry. 1995. Species identification and pathogenicity study of French Colletotrichum strains isolated from strawberry using morphological and cultural characteristics. Phytopathology 85:53-57.

Denoyes, B. and G. Guerin. 1996. Comparison of six inoculation techniques with Colletotrichum acutatum on cold stored strawberry plants and screening for resistance to this fungus in French strawberry collections. Eur. J. Plant Pathol. 102:615-621.

Denoyes, B., I. Amaya, A. Liston, J. Tennessen, T.-L. Ashman, V.M. Whitaker, and T. Hytönen. 2017. Genomics tools available for unravelling mechanisms underlying agronomical traits in strawberry with more to come. Acta Hort. 1156:13-23.

Denoyes-Rothan, B., G. Guérin, C. Délye, B. Smith, M. Minz, M. Maymon, and S. Freeman. 
2003. Genetic diversity and pathogenic variability among isolates of Colletotrichum species from strawberry. Phytopathology 93:219228.

Denoyes-Rothan, B., G. Guérin, E. LerceteauKöhler, and G. Risser. 2005. Inheritance of a race specific resistance to Colletotrichum acutatum in Fragaria $\times$ ananassa. Phytopathology 95:405-412.

Folta, K.M. and T.M. Davis. 2006. Strawberry genes and genomics. Crit. Rev. Plant Sci. 25:399-415.

Forcelini, B.B. and N.A. Peres. 2018. Widespread resistance to QoI fungicides of Colletotrichum acutatum from strawberry nurseries and production fields. Plant Health Prog. 19:338-341.

Galletta, G.J., B.J. Smith, and C.L. Gupton. 1993. Strawberry parent clones US 70, US 159, US 292, and US 438 resistant to anthracnose crown rot. HortScience 28:1055-1056.

Gel Vonauskienè, D., R. Rugienius, T. Šikšnianas, G. Stanienè, A. Sasnauskas, and V. Stanys. 2007. Screening of apple and strawberry plants carrying fungal disease resistance oligogenes using molecular markers. Zemdirbyste-Agr. 94:139-145

Glas, A.S., J.G. Lijmer, M.H. Prins, G.J. Bonsel, and P.M.M. Bossuyt. 2003. The diagnostic odds ratio: A single indicator of test performance. J. Clin. Epidemiol. 56:1129-1135.

Hadonou, A.M., D.J. Sargent, F. Wilson, C.M. James, and D.W. Simpson. 2004. Development of microsatellite markers in Fragaria, their use in genetic diversity analysis, and their potential for genetic linkage mapping. Genome 47:429438 .

Hancock, J.F., T.M. Sjulin, and G.A. Lobos. 2008. Strawberries, p. 393-435. In: J.F. Hancock (ed.). Temperate fruit crop breeding: Germplasm to genomics. Springer, New York, NY.

Haymes, K.M., W.E. Van de Weg, P. Arens, J.L. Maas, B. Vosman, and A.P.M. Den Nijs. 2000. Development of SCAR markers linked to a Phytophthora fragariae resistance gene and their assessment in European and North American strawberry genotypes. J. Amer. Soc. Hort. Sci. 125:330-339.

Horowitz, S., O. Yarden, A. Zveibil, and S. Freeman. 2004. Development of a robust screening method for pathogenicity of Colletotrichum spp. on strawberry seedlings enabling forward genetic studies. Plant Dis. 88:845-851.

Howard, C.M., J.L. Maas, C.K. Chandler, and E.E. Albregts. 1992. Anthracnose of strawberry caused by the Colletotrichum complex in Florida. Plant Dis. 76:976-981.

LaMondia, J.A. 1995. Inhibition with benomyl to growth in vitro of Colletotrichum acutatum and C. fragariae and strawberry fruit infection by benomyl-resistant isolates of C. acutatum. Adv. Strawberry Res. 14:25-30.

Leandro, L.F.S., M.L. Gleason, F.W. Nutter, Jr., S.N. Wegulo, and P.M. Dixon. 2001. Germination and sporulation of Colletotrichum acutatum on symptomless strawberry leaves. Phytopathology 91:659-664.

Lenne, J.M. and D. Wood. 1991. Plant diseases and the use of wild germplasm. Annu. Rev. Phytopathol. 29(1):35-63

Lerceteau-Köhler, E., G. Guérin, and B. DenoyesRothan. 2005. Identification of SCAR markers linked to Rca 2 anthracnose resistance gene and their assessment in strawberry germplasm. Theor. Appl. Genet. 111:862-870.

Lerceteau-Köhler, E., G. Guérin, F. Laigret, and B. Denoyes-Rothan. 2003. Characterization of mixed disomic and polysomic inheritance in the octoploid strawberry (Fragaria $\times$ ananassa) using AFLP mapping. Theor. Appl. Genet. 107:619-628.

Lewers, K.S., W.W. Turechek, S.C. Hokanson, J.L. Maas, J.F. Hancock, S. Serce, and B.J. Smith. 2007. Evaluation of elite native strawberry germplasm for resistance to anthracnose crown rot disease caused by Colletotrichum species. J. Amer. Soc. Hort. Sci. 132:842-849.

Longhi, S., L. Giongo, M. Buti, N. Surbanovski, R. Viola, R. Velasco, J.A. Ward, and D.J. Sargent. 2014. Molecular genetics and genomics of the Rosoideae: State of the art and future perspectives. Hort. Res. 1:1.

Maas, J.L. 1998. Compendium of strawberry diseases. APS Press, St. Paul, MN.

Mertely, J.C., B.B. Forcelini, and N.A. Peres. 2005. Root necrosis of strawberry caused by Colletotrichum acutatum. Univ. Fla., IFAS, EDIS, Publ. No. PP-211. Gainesville, FL.

Mertely, J.C. and N.A. Peres. 2012. Anthracnose fruit rot of strawberry. Univ. Fla., IFAS, EDIS, Publ. No. PP-207. Gainesville, FL.

Miller-Butler, M.A., B.J. Smith, E.M. Babiker, B.R. Kreiser, and E.K. Blythe. 2018. Comparison of whole plant and detached leaf screening techniques for identifying anthracnose resistance in strawberry plants. Plant Dis. 102:2112-2119.

Munir, M., B. Amsden, E. Dixon, L. Vaillancourt, and N.W. Gauthier. 2016. Characterization of Colletotrichum species causing bitter rot of apple in Kentucky orchards. Plant Dis. 100:2194-2203.

Peres, N.A., M.S. Oliveira, and S.J. MacKenzie. 2007. Colletotrichum crown rot (anthracnose crown rot) of strawberries. Univ. Fla., IFAS, EDIS, Publ. No. PP-238. Gainesville, FL.

Rugienius, R., T. Siksnianas, V. Stanys, D. Gel Vonauskiene, and V. Bendokas. 2006. Use of RAPD and SCAR markers for identification of strawberry genotypes carrying red stele (Phytophthora fragariae) resistance gene Rpfl. Agron. Res. 4:335-339.

Salinas, N., S. Verma, N. Peres, and V.M. Whitaker. 2018. FaRCa1: A major subgenome-specific locus conferring resistance to Colletotrichum acutatum in strawberry. Theor. Appl. Genet., doi: 10.1007/s00122-018-3263-7.

Salinas, N.R., J.D. Zurn, M. Mathey, S. Mookerjee, B. Denoyes, J. Perrotte, A. Potier, C.E. Finn, J.F. Hancock, P. Stewart, and N.V. Bassil. 2017. Validation of molecular markers associated with perpetual flowering in octoploid Fragaria germplasm. Mol. Breed. 37:70-82.

Smith, B.J. 1998. Anthracnose crown rot, p. 46-48. In: J.L. Maas (ed.). Compendium of strawberry diseases. 2nd ed. APS Press, St. Paul, MN

Smith, B.J. and L.L. Black. 1987. Resistance of strawberry plants to Colletotrichum fragariae affected by environmental conditions. Plant Dis. 71:834-837.

Smith, B.J. and L.L. Black. 1990. Morphological, cultural, and pathogenic variation among $\mathrm{Col}$ letotrichum species isolated from strawberry. Plant Dis. 74:69-76.

Smith, B.J. and L.L. Black. 1992. In vitro activity of fungicides against Colletotrichum fragariae. Acta Hort. 348:509-512.

Smith, B.J. and L.L. Black. 1993. In vitro fungicide studies show the occurrence of benomylresistant Colletotrichum spp. from strawberry. Adv. Strawberry Res. 12:42-48.

Smith, B.J., C.L. Gupton, G.J. Galletta, J.L. Maas, J.M. Enns, J.R. Ballington, Jr., R.J. Constantin, T.J. DiVittorio, and D. Himelrick. 1998. 'Pelican' strawberry. HortScience 33:1082-1084.

Smith, B.J. and J.M. Spiers. 1982. Evaluating techniques for screening strawberry seedlings for resistance to Colletotrichum fragariae. Plant Dis. 66:559-561.

Ureña-Padilla, A.R., S.J. MacKenzie, B.W. Bowen, and D.E. Legard. 2002. Etiology and population genetics of Colletotrichum spp. causing crown and fruit rot of strawberry. Phytopathology 92:1245-1252.

Van de Weg, W.E., H.J. Schouten, and B. Henken. 1997. Monogenicity of Rpfl conferring resistance in strawberry to Phytophthora fragariae var. fragariae, p. 71-77. In: W.E. Van de Weg (ed.). Gene-for-gene relationships between strawberry and the causal agent of red stele root rot, Phytophthora fragariae var. fragariae. CPRODLO, Wageningen, Netherlands.

Whitaker, V.M., S. Lee, L.F. Osorio, S. Verma, J.A. Roach, J. Mangandi, Y.-H. Noh, S. Gezan, and N. Peres. 2017. Advances in strawberry breeding at the University of Florida. Acta Hort. 1156:1-6. 